\title{
Tensile Testing of Irradiated Grade 92 Ferritic-Martensitic Steels at the IMET Hot Cell Facility
}

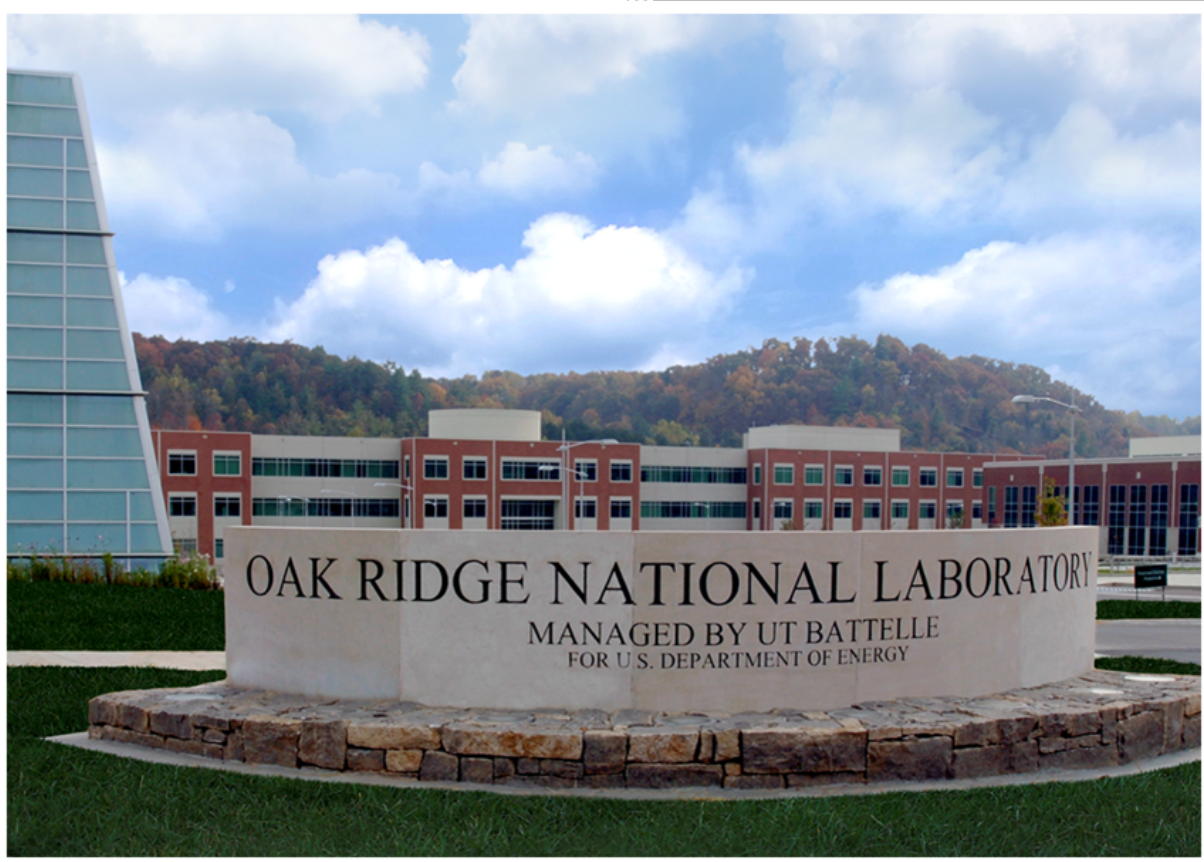

Alicia Raftery Lizhen Tan Hideo Sakasegawa Kory Linton

April 2018 


\section{DOCUMENT AVAILABILITY}

Reports produced after January 1, 1996, are generally available free via US Department of Energy (DOE) SciTech Connect.

Website http://www.osti.gov/scitech/

Reports produced before January 1, 1996, may be purchased by members of the public from the following source:

National Technical Information Service

5285 Port Royal Road

Springfield, VA 22161

Telephone 703-605-6000 (1-800-553-6847)

TDD 703-487-4639

Fax 703-605-6900

E-mail info@ntis.gov

Website http://classic.ntis.gov/

Reports are available to DOE employees, DOE contractors, Energy Technology Data Exchange representatives, and International Nuclear Information System representatives from the following source:

Office of Scientific and Technical Information

PO Box 62

Oak Ridge, TN 37831

Telephone 865-576-8401

Fax 865-576-5728

E-mail reports@osti.gov

Website http://www.osti.gov/contact.html

This report was prepared as an account of work sponsored by an agency of the United States Government. Neither the United States Government nor any agency thereof, nor any of their employees, makes any warranty, express or implied, or assumes any legal liability or responsibility for the accuracy, completeness, or usefulness of any information, apparatus, product, or process disclosed, or represents that its use would not infringe privately owned rights. Reference herein to any specific commercial product, process, or service by trade name, trademark, manufacturer, or otherwise, does not necessarily constitute or imply its endorsement, recommendation, or favoring by the United States Government or any agency thereof. The views and opinions of authors expressed herein do not necessarily state or reflect those of the United States Government or any agency thereof. 
Fusion \& Materials for Nuclear Systems Division

\title{
Tensile Testing of Irradiated Grade 92 Ferritic-Martensitic Steels at the IMET Hot Cell
} Facility

\author{
Alicia Raftery \\ Lizhen Tan \\ Hideo Sakasegawa \\ Kory Linton
}

Date Published: April 2018

\section{NSUF Work Package \#: UF-18OR021003 \\ Work Package Manager: Kory Linton \\ Milestone \#: M3UF-18OR0210032}

\author{
Prepared by \\ OAK RIDGE NATIONAL LABORATORY \\ Oak Ridge, TN 37831-6283 \\ managed by \\ UT-BATTELLE, LLC \\ for the \\ US DEPARTMENT OF ENERGY \\ under contract DE-AC05-00OR22725
}





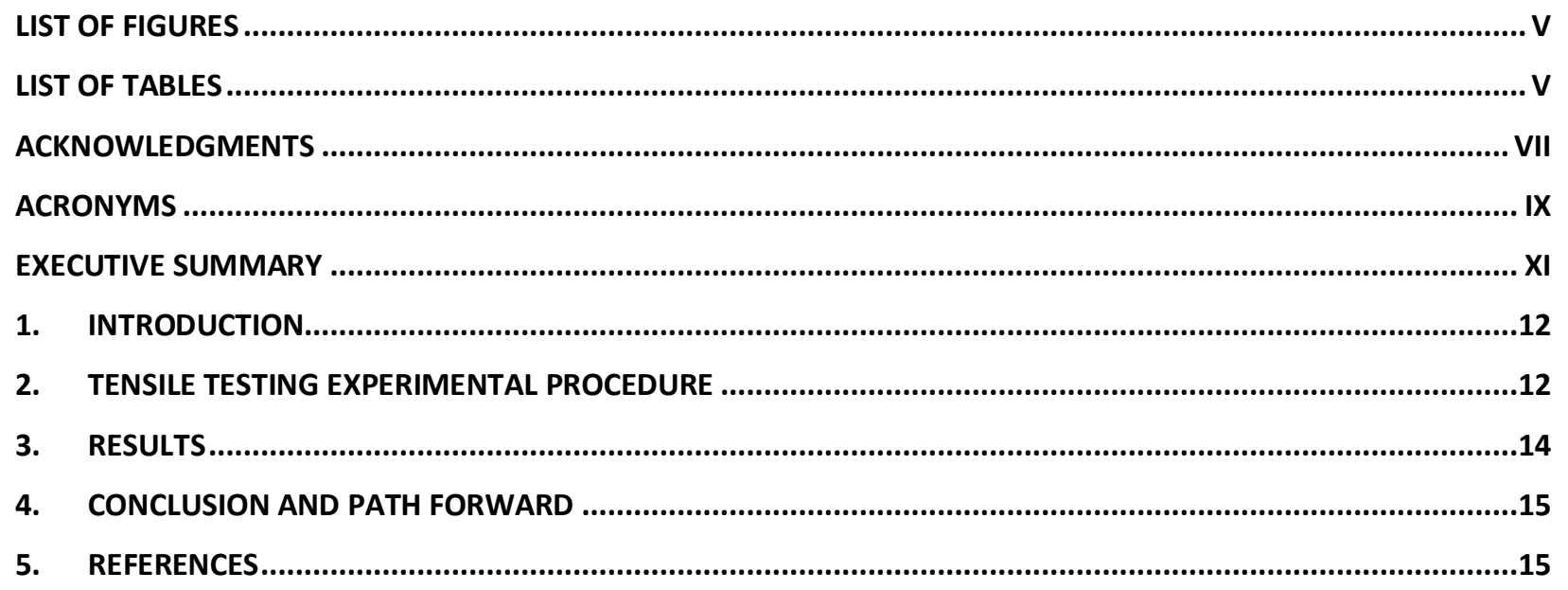





\section{LIST OF FIGURES}

Figure 1. SS-J2 Specimen GB05 pictured before irradiation......................................................... 13

Figure 2. Instron machine used for tensile testing, which is located in Cell 2 at the IMET facility........... 13

Figure 3. Results from tensile testing of (a) GB04, (b) GB05, (c) GB11, (d) GB12, and (e) TA04......... 14

\section{LIST OF TABLES}

Table 1. List of irradiation conditions for tensile tested specimens. ..................................................... 13 



\section{ACKNOWLEDGMENTS}

This research used resources at the LAMDA laboratory operated by the Oak Ridge National Laboratory. Funding for this research was provided by the US Department of Energy, Office of Nuclear Energy Nuclear Science User Facility. This report was authored by UT-Battelle, LLC under Contract No. DEAC05-00OR22725 with the US Department of Energy. 



\section{ACRONYMS}

FM Ferritic-martensitic

IMET Irradiated Materials Examination and Testing

ORNL Oak Ridge National Laboratory

PIE Post-Irradiation Examination

NSUF Nuclear Science User Facilities

HFIR High Flux Isotope Reactor

CINR Consolidated Innovative Nuclear Research

LAMDA Low Activation Materials Development and Analysis

SEM Scanning Electron Microscopy

TEM Transmission Electron Microscopy 



\section{EXECUTIVE SUMMARY}

This report summarizes the completed post-irradiation tensile testing of five ferritic-martensitic (FM) steel SS-J2 specimens at the Irradiated Materials Examination and Testing (IMET) hot cell facility at Oak Ridge National Laboratory (ORNL). A brief description of the motivation for the study, the properties and irradiation conditions of the samples, and the tensile testing conditions are provided. The results will be used to compare the mechanical properties of the irradiated specimens to un-irradiated conditions to determine how irradiation affects the steel alloy material behavior. 


\section{INTRODUCTION}

Stainless steels are used for a number of structural components in nuclear reactors, including pressure tubes, which are used in-core and exposed directly to radiation. Steels used for nuclear applications must be able to retain mechanical properties during irradiation to ensure the safe performance of reactors. The recent development of a number of high-performance stainless steels has provided the prospect of materials that may surpass the irradiation performance of currently used steels. Specifically, modern ferritic-martensitic (FM) steels have an improved thermal conductivity, high-temperature stability, and void swelling compared to currently used steels $[1,2]$. In addition, innovative steels may have the potential to be used in next generation nuclear systems, which have higher operating temperatures and more severe neutron flux conditions [3]. Compared to the classic FM steel Grade 91 that has been used in varied types of reactors, Grade 92 generally has greater tensile and creep strengths, which provides better safety margins and economics. Irradiation testing of new steel alloys is necessary to evaluate the materials for future reactor applications. Post-irradiation examination (PIE) of irradiated steels can determine the effects of irradiation on mechanical properties and microstructural evolution, thereby providing insight into the development of advanced alloys.

Oak Ridge National Laboratory (ORNL) has a number of PIE capabilities under the Nuclear Science User Facility (NSUF) program to test mechanical properties, including in-cell tensile testing of sub-sized (SSJ2) tensile specimens. This report summarizes the tensile testing of five irradiated ferritic-martensitic steel specimens that were previously irradiated in the High Flux Isotope Reactor (HFIR). The purpose of the tensile testing is to investigate the post-irradiation mechanical behavior of FM steel Grade 92 and provide data to evaluate the performance of this material for potential use in current and advanced nuclear reactor applications. Radiation resistance of three heats of Grade 92 are to be examined in this CINR NSUF FY2017 project. One of the heats is optimized Grade 92, developed under the Advanced Reactor Concept program. Its tensile test results are reported here. The other two heats are commercial Grade 92, which will be examined and reported separately in near future.

\section{TENSILE TESTING EXPERIMENTAL PROCEDURE}

Five irradiated SS-J2 tensile specimens were tested in air at room temperature in an Instron ElectroPuls E1000 test system, which is located in Cell 2 at the Irradiated Materials Examination and Testing (IMET) hot cell facility. Table 1 shows a list of the specimens and their associated irradiation conditions. The specimens were irradiated with different conditions in order to isolate the effect of dose and temperature on the mechanical properties. The geometry for the SS-J2 specimen is $4.0 \times 16.0 \times 0.5 \mathrm{~mm}$ with a gauge section of $1.2 \times 5.0 \times 0.5 \mathrm{~mm}$ (Figure 1). The samples were loaded in the Instron machine (Figure 2) and tested under a fixed crosshead speed, which causes a fixed strain rate. The crosshead speed during the tensile test was $0.012 \mathrm{in} / \mathrm{min}$ and the corresponding strain rate was $0.001 \mathrm{~s}^{-1}$. The elongation response of the material is recorded throughout the test in order to produce tensile curves until the point at which the strain causes rupturing of the specimen. 


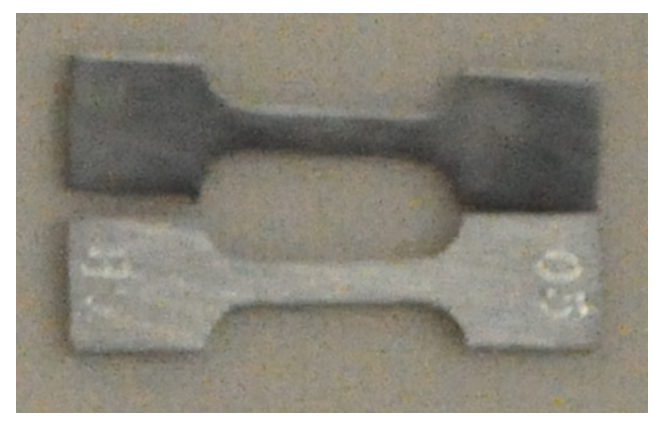

Figure 1. SS-J2 Specimen GB05 pictured before irradiation.

Table 1. List of irradiation conditions for tensile tested specimens.

\begin{tabular}{|c|c|c|c|}
\hline Sample ID & Material Alloy & Dose [dpa] & Temperature $\left[{ }^{\circ} \mathbf{C}\right]$ \\
\hline GB04 & FM (9Cr-2WVNb) & 7 & 300 \\
\hline GB05 & FM (9Cr-2WVNb & 14 & 300 \\
\hline GB11 & FM (9Cr-2WVNb) & 7 & 650 \\
\hline GB12 & FM (9Cr-2WVNb & 14 & 650 \\
\hline TA04 & FM (9Cr-1WVTa) & 7.4 & 300 \\
\hline
\end{tabular}

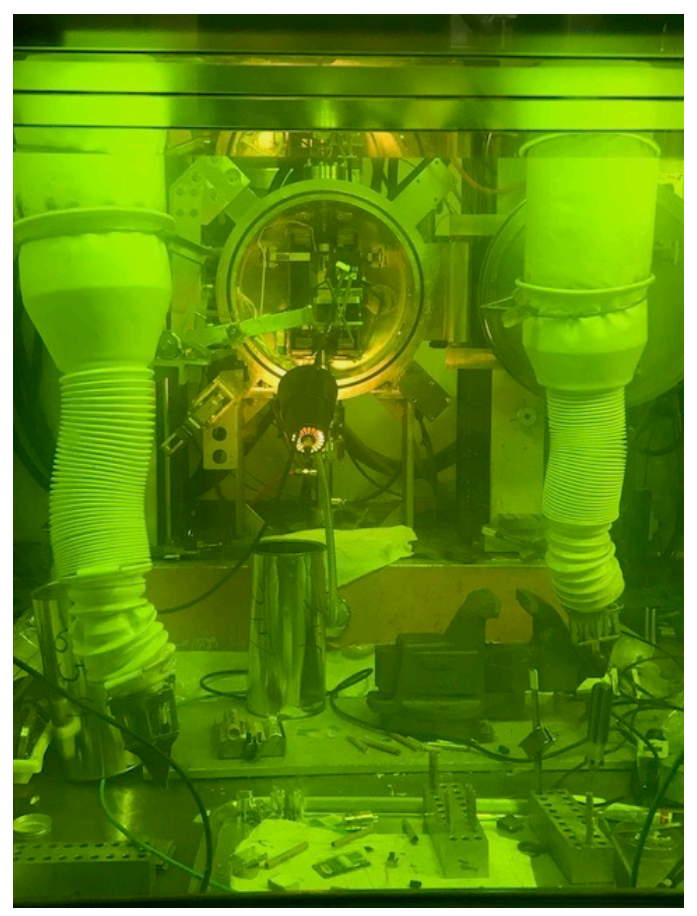

Figure 2. Instron machine used for tensile testing, which is located in Cell 2 at the IMET facility. 


\section{RESULTS}

The resulting tensile curves for each tested specimen are shown in Figure 3. The data that will be extracted from these tensile curves during the analysis include material properties such as yield strength, uniform elongation, and ultimate strength. These curves will be compared to the reference un-irradiated tensile curve for these alloys in order to determine the evolution of the mechanical behavior as a function of temperature and accumulated dose.

(a)

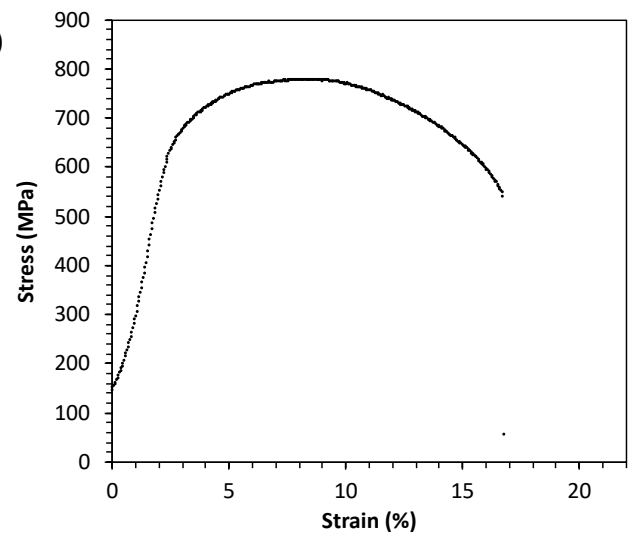

(c)

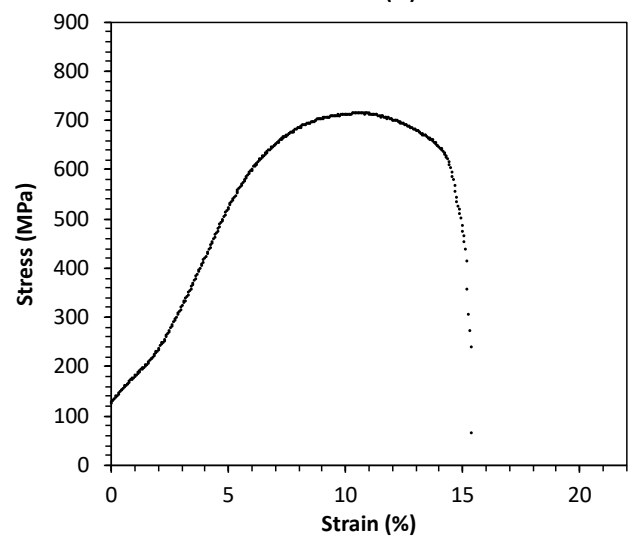

(b)

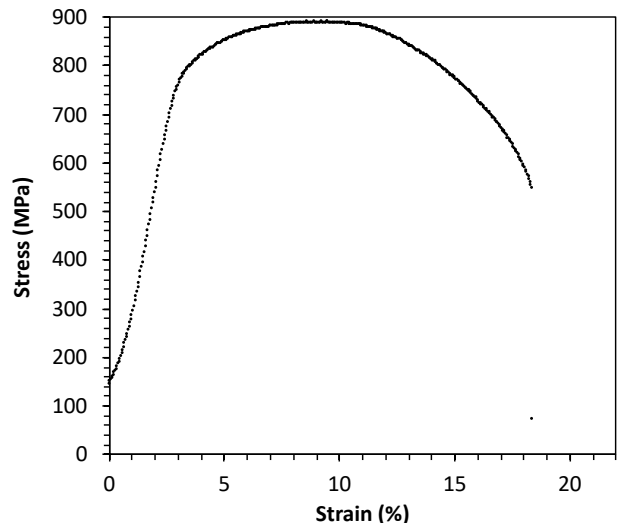

(d)

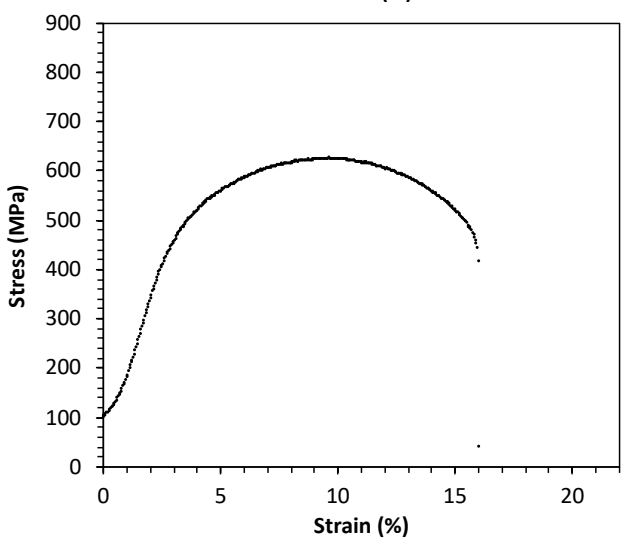

(e)

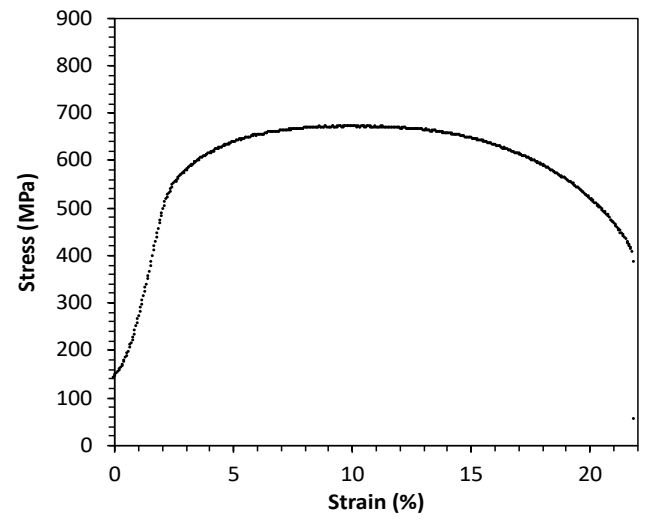

Figure 3. Results from tensile testing of (a) GB04, (b) GB05, (c) GB11, (d) GB12, and (e) TA04. 


\section{CONCLUSION AND PATH FORWARD}

The successful completion of the 2018 NSUF Milestone "Tensile testing of GB specimens currently located at ORNL" consisted of tensile testing five neutron irradiated ferritic-martensitic steel specimens. The tensile tests were done at the IMET hot cell facility at ORNL. The next step in this research is to investigate the resulting microstructures of these specimens. Therefore, one-half of each ruptured specimen has been shipped to the Low Activation Materials Development and Analysis (LAMDA) laboratory, where further characterization will take place. Characterization techniques that will be utilized at LAMDA include Scanning Electron Microscopy (SEM), nano-indentation, and Transmission Electron Microscopy (TEM). These results will provide an in-depth understanding of the evolution of the FM Grade 92 alloy microstructure and mechanical properties during irradiation and will help evaluate whether this steel is suitable for use in a nuclear reactor.

\section{REFERENCES}

[1] Kluek, R.L., "Elevated temperature ferritic and martensitic steels and their applications to future nuclear reactors," International Materials Review, Vol. 50 (2005): 287-310.

[2] Gilbon, D. and C. Rivera, "Behavior of different ferritic steels under ion, electron, and fast neutron irradiation," Journal of Nuclear Materials, 155 (1988): 1268-1273.

[3] Gelles, D.S., "Development of martensitic steels for high neutron damage applications," Journal of Nuclear Materials, 239 (1996): 99-106. 